The current issue and full text archive of this journal is available on AFEBI Management and Business Review at:

https://journal.afebi.org/index.php/ambr/article/view/481

\title{
INFLUENCE OF FLEXIBLE WORK ARRANGEMENT AND WORK ENVIRONMENT ON EMPLOYEE PERFORMANCE THROUGH WORK-LIFE BALANCE
}

\author{
Aditya Indra Bagaskara* \\ Hilmiana \\ Irfanul Kamal \\ Universitas Padjadjaran, Bandung, Indonesia
}

\begin{abstract}
The success of an organization is influenced by employee performance, so every company will try to improve the performance of its employees in achieving the organizational goals that have been set. During the Covid-19 pandemic, there are several factors that can support employee performance, one of which is flexible work arrangements. However, not only work methods are needed to improve employee performance, the work environment and aspects of work-life balance are expected to improve employee performance. This study aims to determine the effect of flexible work arrangements and work environment on employee performance directly or indirectly through work-life balances as an intervening variable. The data in this study were collected by distributing online questionnaires. This research on employees of PT. Telkom Indonesia, tbk in West Java ( $\mathrm{S}=193)$, where $\mathrm{S}$ is the sample of employees at Telkom West Java. The method used in this research is PLS-SEM which is processed using Smart PLS 3 software. The results showed that there was a direct influence between flexible work arrangements and work environment on employee performance. In addition, the results of other studies also show that there is an indirect effect between flexible work arrangements and work environment on employee performance through work-life balance as an intervening variable.
\end{abstract}

Keywords: Flexible Working Arrangement, Work Environment, Work Life Balance, Employee Performance

*Corresponding author. Email address: aditya19002@mail.unpad.ac.id

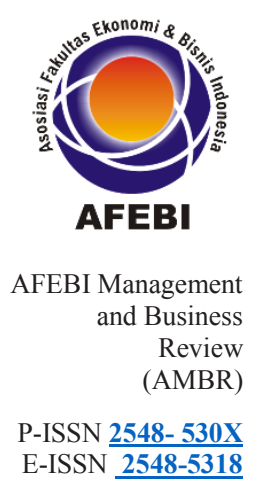

Influence of

Flexible Work

Arrangement and

Work

Environment on

Employee

Performance

Through Work-

Life Ballance

Received

August $6^{\text {th }} 2021$

Review

September $14^{\text {th }} 2021$

Publish

September 22 ${ }^{\text {nd }} 2021$ 
Every organization has an identity that functions as a value or organizational identity in the organizational environment. Organizational identity is an effort to introduce oneself to the public as a form of the existence and accountability of the organization to the vision and mission of the organization. The identity of an organization can be a differentiator between one company and another. An organization that has a strong identity cannot be separated from members who excel in organizational commitment, self-competence and have good intellectual capital. Superior HR (Human Resources) cannot be separated from the role of human capital which functions to develop HR in the Organization. Even today, HR competence also gives its own weight to the assessment of an organization.

According to Ulrich et al., (2001) HR is the design of a formal system in an organization to ensure the use of talent and human potential effectively and efficiently to achieve organizational goals. Ulrich et al., (2001) also mention the new role of HR is to support the competence of the resources themselves that are demanded by the organization to survive by always providing the best performance for the organization. It is natural for organizations to want to get the best performance from a series of systems within the organization. Human Resource Management is one of the key factors to get good performance for an organization, in addition to dealing with skills and expertise issues, HR management is also obliged to build conducive behaviour for employees to get the best performance.

The year 2020 is a tough year for all countries in the world due to the Covid-19 virus pandemic, Indonesia is no exception. Almost all industrial sectors have weakened due to the impact of this pandemic, there are even industries that have gone out of business. During the horrors of the Covid-19 pandemic, the Indonesian government took a 50:50 policy in responding to the pandemic, which was to allow people to continue working by complying with health protocols or working from home or WFH (Work from Home). This policy was taken by the Indonesian government because if the Indonesian economy worsens, the Indonesian government will be increasingly overwhelmed by this pandemic.

PT. Telkom Indonesia, tbk is a state-owned company engaged in telecommunications with one of its trademarks being IndiHome. PT. Telkom Indonesia, tbk or better known as Telkom is a company that prioritizes human resources. This is evidenced by the existence of the Directorate of HCM (Human Capital Management) which functions to manage and develop human resources at Telkom. As a BUMN, Telkom is tasked with providing telecommunications service facilities and infrastructure (especially the internet) to the wider community to remote areas throughout Indonesia. Telkom's goal in 2021 is "To create a more prosperous and competitive nation and to provide the best-added value for stakeholders".

During the Covid-19 pandemic, employees are forced to adapt to be able to work from home (WFH), work in offices (WFO), or from anywhere while still complying with protocols (FWA). Nguyen et al., (2015) and Chandra \& Priyono (2016) through Hastutiningsih, (2019) simultaneously through their research state that the work environment has a positive effect on employee performance. Adhitama \& Riyanto, (2020) argue that the needs of each employee's work environment are unique, if the company can provide the work environment that every employee need, it will improve employee performance and motivation.

Organizations that implement FWA have an awareness that changes in dynamics and flexible work patterns can make employees have better aspects of Work Life Balance (WLB), resulting in good performance as well (Garg \& Yajurvedi, 2016). According to Singh and Khanna through Tumbel et al., (2017) WLB is a broad concept that involves setting the right priorities between work (career and ambition) on the one hand and life (happiness, leisure, family, and spiritual development). Meanwhile, according to Handayani \& Munawar, (2015), WLB is a condition when a person can share roles at home and at work and feel satisfaction in these roles.

Prior to the pandemic, most employees had high mobility at work so it would be a waste of time and could cause feelings of being physically and mentally burdened. On the other hand, employees have a need to fulfil their social status both in the home and family environment, this can trigger a conflict of interest for employees if there are aspects that are not met. During the Covid-19 pandemic, changing the way employees work to online methods can affect aspects of WLB. This is supported by the results of pre-research questionnaires that have been filled out by respondents, that WLB is an aspect that makes their performance improve.

Based on the above background, the performance of Telkom employees during the Covid-19 pandemic is very interesting to study by linking FWA factors, the work environment and WLB. In this study, the application of the FWA method triggers changes in the work environment and aspects of employee WLB. Therefore, researchers are interested in analysing more deeply about "The Influence of Flexy Work Arrangements and Work Environments on Employee Performance Through Work Life Balance During the Covid-19 Pandemic".

\section{LITERATURE STUDY}

The world was shocked by the Covid-19 pandemic in 2020. The impact of this pandemic disrupts activities in various sectors, one of the sectors most affected is the economic sector. Many companies in the world have experienced a decline in revenue due to this epidemic (Hartono \& Rahadi, 2021). Companies operating during the 
Covid-19 pandemic must comply with existing health protocols. Some employees who work at the company are temporarily laid off and some are working from home (Work from Home).

As stated by Dingel \& Neiman, (2020) through (Hartono \& Rahadi, 2021) that work cannot be done from home. The theory proves that working from home is not easy, let alone improving performance. Basically, employee performance is seen from the quality of work, quantity of work, discipline, effectiveness, and timeliness of employees at work (Mathis \& Jackson, 2014). The dimensions of employee performance can trigger a company's competition with other companies. Companies that have good employee performance will easily achieve their goals. Therefore, it is natural that companies want to get the best performance from their employees. The Covid 19 pandemic that has hit the world has changed all aspects of people's lives, from lifestyle, work habits, to the management of human resources within companies. The government's policy to limit physical and social contact has limited the lifestyle of gathering with many people, the world of work in all sectors has changed, not only in the economic sector but also in the Human Resources management sector. This condition causes some employees who previously worked from office (WFO) to work from home (WFH).

WLB is achieved by an employee when he can comfortably meet the demands of his work and personal life. WLB in the formal sector shows that the flexibility of working hours if less will cause a decrease in employee satisfaction and performance, but in the informal sector the flexibility of working hours has an indirect effect on performance (Putranti \& Susilo, 2020). Every individual's WLB is different from time to time, often every day it can change, including during this pandemic. The WLB that is right for today may be different in the future.

The Flexible Working Arrangement (FWA) was initiated by the drive to change the way the world's big companies work, especially digital companies (Google, Apple, Microsoft, Facebook) that can do their jobs without having to be in the office. FWA is also supported by tools for virtual collaboration that allow the execution of work without the need to meet physically. According to SHRM, (2015) FWA is a method of working in various ways, such as telecommuting, compressed work weeks, and flexible scheduling that make employees more flexible in their work. In addition, another definition of FWA according to Stefanie et al., (2020) is a choice of work that allows flexibility in terms of "where" where the work is completed or commonly referred to as telecommuting/flex place or "when" the work can be done. finished. complete.

The work environment during the Covid-19 pandemic can be divided into two. The first work environment is a work environment at home when employees do WFH and the second work environment is a work environment in the office when employees are required to do WFO. Both of these work environments can affect employee performance. As stated by Hustia, (2020) that a good work environment will also have a good impact on employee performance, so having a conducive work environment is a must for an employee.

\section{RESEARCH METHODOLOGY}

To understand the decision-making process in the cultural villages, we use a systematic review method. In this This research method is quantitative because it aims to examine a population or a sample of a particular population with data collected through research instruments to test hypotheses that have been determined in accordance with the research conducted. In this research, the population is 342 employees who worked at PT. Telkom Indonesia, tbk Region West Java and the minimum sample is 175 respondents. In this reasearch Author success collect 193 answers from respondents using online questionnaire, details of the data can be seen in table 1. The method used in this research is descriptive with a verification approach. Descriptive method is applied by describing the data that has been collected as it is without intending to make general conclusions.

\begin{tabular}{ccc}
\hline Region & Frequency & Percentage \\
\hline Bandung & 45 & $23.32 \%$ \\
Bandung Barat & 31 & $16.06 \%$ \\
Cirebon & 33 & $17.10 \%$ \\
Karawang & 27 & $13.99 \%$ \\
Sukabumi & 32 & $16.58 \%$ \\
Tasikmalaya & 25 & $12.95 \%$ \\
Total & $\mathbf{1 9 3}$ & $\mathbf{1 0 0 \%}$ \\
\hline
\end{tabular}

Table 1

Source: Data Processing (2021) 
Meanwhile, to test the hypothesis that has been set, in this study a verification approach will be carried out. With reference to the purpose of the first research, descriptive method is used to provide an overview of the variables studied, namely flexible work arrangements, work environment, work-life balance and employee performance. In addition, the verification approach is used to explain the extent of the relationship between variables, either directly or indirectly.

The analysis method begins by looking at the characteristics of the data through descriptive statistics and then analyzing the Multivariate Data Analysis (MDA) model using the Partial Least Square (PLS) method. The PLS model is used in this study because the model can predict constructions built from several variables and can explain complex structural models. This research also involves several variables with dimensions that are adjusted to be more relevant to the industry discussion, thus forming formative variables. The paradigm of this research can be seen in Figure 1 below:

\section{Figure 1}

Research

Conceptual Model

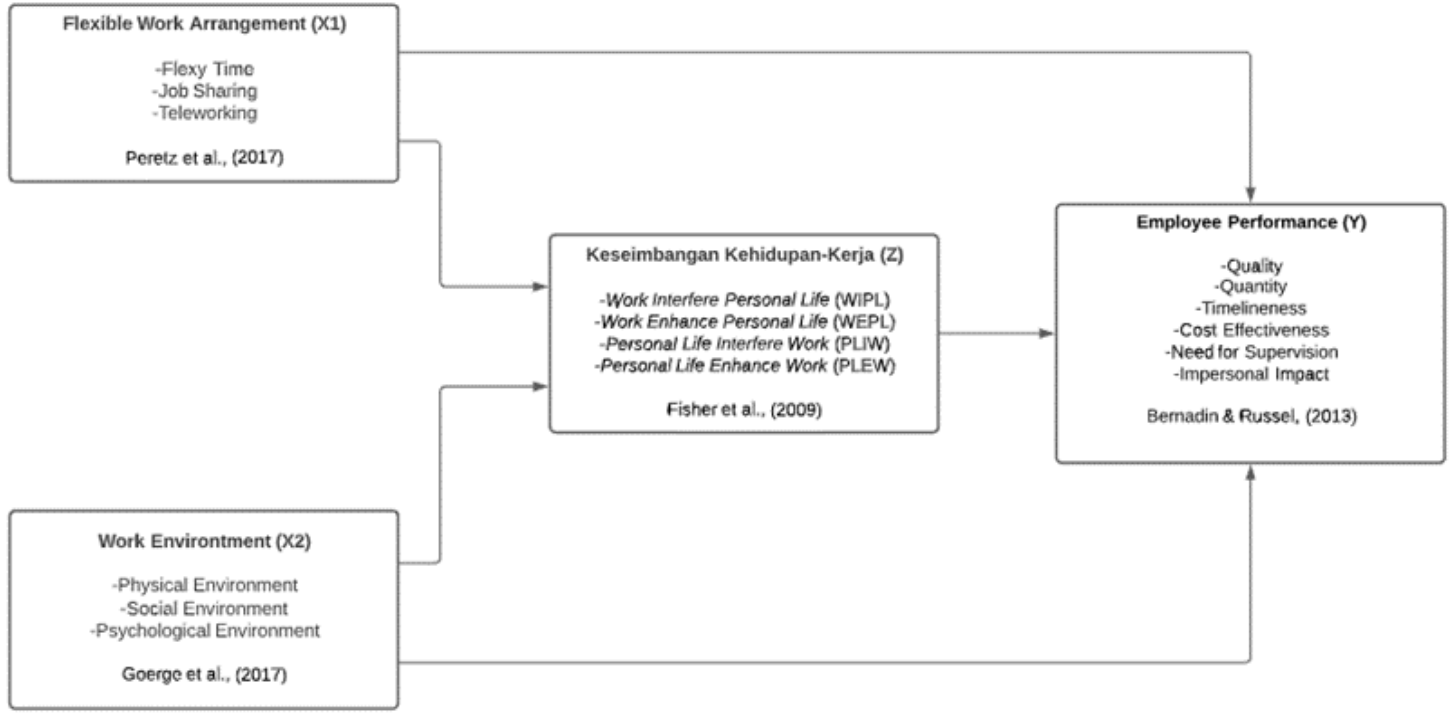

From the research conceptual model in figure 1, the following hypotheses can be formulated:

H1: Flexible Work Arrangement has a significant positive effect on Work Life Balance

H2: Work Environtment has a significant positive effect on Work Life Balance

H3: Flexible Work Arrangement has a significant positive effect on Employee Performance

H4: Work Environment has a significant positive effect on Employee Performance

H5: Work Life Balance has a significant positive effect on Employee Performance

H6: Flexible Work Arrangement has a significant positive effect on Employee Performance through Work Life Balance

H7: Work Environment has a significant positive effect on Employee Performance through Work Life Balance

\section{RESULT AND DISCUSSION}

\section{Table 2}

Recapitulation of Descriptive Analysis of Flexible Work Arrangement Variables (X1)

\section{Descriptive Analysis of Variables}

The questionnaire regarding respondents' responses to the Flexible Work Arrangement (X1) variable consists of 3 dimensions (Flexy Time, Job Sharing, and Teleworking/Flexy Place), 8 statement items, and 193 respondents. The following are the results of the recapitulation of data processing that has been carried out regarding the dimensions of the Flexible Work Arrangement (X1) variable, which are presented as follows:

\begin{tabular}{ccccc}
\hline No. & Dimension & Total Score & Average & Category \\
\hline 1 & Flexy Time & 814.00 & 4.22 & Very high \\
2 & Job Sharing & 792.00 & 4.10 & High \\
3 & Teleworking / Flexy Place & 812.67 & 4.21 & Very high \\
& Average & $\mathbf{8 0 6 . 2 2}$ & $\mathbf{4 . 1 8}$ & High \\
\hline
\end{tabular}

Source: Data Processing (2021) 
Based on table 2, the average respondents' responses to the Flexible Work Arrangement variable (X1). The high fulfilment of the Flexy Time dimension occurs because every human being has their own productive hours which if working at that time can increase their performance productivity. The low dimension of job sharing occurs because online communication is a new habit, so there are still frequent communication problems between employees. The achievement of the Flexible Work Arrangement aspect is due to the compatibility of the existing work culture with the Flexible Work Arrangement work method that was recently implemented by Telkom Management during the pandemic. The score interpretation criteria for the Flexible Work Arrangement variable with a value of 4.18 is high.

The questionnaire regarding respondents' opinions about the Work Environment variable (X2) consists of 3 dimensions (Physical Conditions, Social Conditions, and Psychological Conditions), 9 statement items, and 193 respondents. The following presents the results of data processing that has been carried out regarding the dimensions of the Work Environment (X2) variable as follows:

\begin{tabular}{ccccc}
\hline No. & Dimension & Total Score & Average & Category \\
\hline $\mathbf{1}$ & Physical condition & 836.50 & 4.33 & Very high \\
$\mathbf{2}$ & Social Condition & 819.67 & 4.25 & Very high \\
$\mathbf{3}$ & Psychological Condition & 721.50 & 3.74 & High \\
& Average & $\mathbf{7 9 2 . 5 6}$ & $\mathbf{4 . 1 1}$ & High \\
\hline
\end{tabular}

Source: Data Processing (2021)

Based on table 3, the average respondents' responses to the Work Environment variable (X2). The physical condition of an employee's work environment can greatly affect their productivity, this can happen because they will feel comfortable and relaxed if they are in a place they like. During the pandemic, employees must limit their movement space so as not to be exposed to the Covid-19 virus, but employees are still free to determine their own workplace and time even though boredom and boredom may arise. The criteria for interpreting the score on the work environment variable with a value of 4.11 is high.

The questionnaire regarding respondents' opinions about the Work Life Balance $(Z)$ variable consists of 4 dimensions of Work Interfere Personal Life (WIPL), Work Enhance Personal Life (WEPL), Personal Life Interfere Work (PLIW), and Personal Life Enhance Work (PLEW)), 9 statement items, and 193 respondents. The following presents the results of data processing that has been carried out regarding the dimensions of the Work Life Balance (Z) variable as follows:

\begin{tabular}{lllll}
\hline No. & Dimension & Total Score & Average & Category \\
\hline $\mathbf{1}$ & Work Interfere Personal Life (WIPL) & 806.33 & 4.18 & High \\
$\mathbf{2}$ & Work Enhance Personal Life (WEPL) & 797.50 & 4.13 & High \\
$\mathbf{3}$ & Personal Life Interfere Work (PLIW) & 780.00 & 4.04 & High \\
$\mathbf{4}$ & Personal Life Enhance Work (PLEW) & 772.00 & 4.00 & High \\
& Average & $\mathbf{7 8 8 . 9 6}$ & $\mathbf{4 . 0 9}$ & High \\
\hline
\end{tabular}

Source: Data Processing (2021)

Based on table 4, the average respondents' responses regarding the Work Life Balance $(\mathrm{Z})$ variable. Work Interfere Personal Life is the dimension with the highest value because during the pandemic, employees do not feel that their personal lives are disturbed by work. While the lowest average is for the Enhance Personal Life Work (PLEW) dimension, this can happen because during a pandemic personal life can easily interfere with work life and motivate work life. According to most respondents, even in a pandemic, they can still communicate and interact with their friends or family and can still carry out their hobbies. In addition, the combination of personal life and work life is an important aspect to maintain their Work Life Balance. The score interpretation criteria on the Work Life Balance variable with a value of 4.09 is high.

The questionnaire regarding respondents' opinions about Employee Performance (Y) consists of 6 dimensions Quality, Quantity, Timeliness, Cost Effectiveness, Needs Supervision, and Impersonal Impact, 12 statement items, and 193 respondents. The following is a recapitulation of the results of data processing that has been carried out regarding the dimensions of the Employee Performance variable (Y) as follows:
Influence of

Flexible Work

Arrangement and

Work

Environment on

Employee

Performance

Through Work-

Life Balance

Table 3

Recapitulation of

Descriptive

Analysis of Work

Environment

Variables (X2)

Table 4

Recapitulation of

Descriptive

Analysis of Work

Life Balance (Z)

Variables 
AMBR

Table 5

Recapitulation of Descriptive Analysis of Employee Performance Variables (Y)

Table 6

Construct's Loading Factor Validity Result

\begin{tabular}{ccccc}
\hline No. & Dimension & Total Score & Average & Category \\
\hline $\mathbf{1}$ & Quality & 867.50 & 4.49 & Very high \\
$\mathbf{2}$ & Quantity & 851.50 & 4.41 & Very high \\
$\mathbf{3}$ & Timeliness & 857.50 & 4.44 & Very high \\
$\mathbf{4}$ & Cost Effectiveness & 864.00 & 4.48 & Very high \\
$\mathbf{5}$ & Need for Supervision & 855.50 & 4.43 & Very high \\
$\mathbf{6}$ & Impersonal Impact & 878.00 & 4.55 & Very high \\
& Average & $\mathbf{8 6 2 . 3 3}$ & $\mathbf{4 . 4 7}$ & Very high \\
\hline
\end{tabular}

Source: Data Processing (2021)

Based on table 5, the average respondents' responses regarding the Employee Performance variable (Y). The high dimension of Impersonal Impact is because respondents can collaborate well during the pandemic. Although the quantity dimension is the lowest, most of the respondents are still able to complete their work well. According to respondents, even during the pandemic they were still able to complete their work very well, as evidenced by all dimensions being in the very high category. The criteria for interpretation of the score on the Employee Performance variable with a value of 4.47 is very high.

\section{Outer Model Evaluation}

\section{Validity Test}

\begin{tabular}{|c|c|c|c|c|c|c|c|}
\hline Construct & Loading Factor & Critical & Result & Construct & Loading Factor & Critical & Result \\
\hline X1.1.1 & 0.916 & 0.5 & Valid & Y.6.1 & 0.923 & 0.5 & Valid \\
\hline $\mathrm{X} 1.1 .2$ & 0.924 & 0.5 & Valid & Y.6.2 & 0.916 & 0.5 & Valid \\
\hline $\mathrm{X} 1.1 .3$ & 0.903 & 0.5 & Valid & Z.1.1 & 0.942 & 0.5 & Valid \\
\hline $\mathrm{X} 1.2 .1$ & 0.929 & 0.5 & Valid & Z.1.2 & 0.939 & 0.5 & Valid \\
\hline $\mathrm{X} 1.2 .2$ & 0.935 & 0.5 & Valid & Z.2.1 & 0.907 & 0.5 & Valid \\
\hline $\mathrm{X} 1.3 .1$ & 0.924 & 0.5 & Valid & Z.2.2 & 0.913 & 0.5 & Valid \\
\hline $\mathrm{X} 1.3 .2$ & 0.923 & 0.5 & Valid & Z.3.1 & 0.933 & 0.5 & Valid \\
\hline $\mathrm{X} 1.3 .3$ & 0.903 & 0.5 & Valid & Z.3.2 & 0.925 & 0.5 & Valid \\
\hline $\mathrm{X} 2.1 .1$ & 0.846 & 0.5 & Valid & Z.4.1 & 0.911 & 0.5 & Valid \\
\hline $\mathrm{X} 2.1 .2$ & 0.866 & 0.5 & Valid & Z.4.2 & 0.865 & 0.5 & Valid \\
\hline $\mathrm{X} 2.1 .3$ & 0.831 & 0.5 & Valid & $\mathrm{X} 1.1$ & 0.946 & 0.5 & Valid \\
\hline $\mathrm{X} 2.1 .4$ & 0.829 & 0.5 & Valid & $\mathrm{X} 1.2$ & 0.836 & 0.5 & Valid \\
\hline $\mathrm{X} 2.2 .1$ & 0.910 & 0.5 & Valid & $\mathrm{X} 1.3$ & 0.940 & 0.5 & Valid \\
\hline $\mathrm{X} 2.2 .2$ & 0.918 & 0.5 & Valid & $\mathrm{X} 2.1$ & 0.924 & 0.5 & Valid \\
\hline $\mathrm{X} 2.3 .1$ & 0.939 & 0.5 & Valid & $\mathrm{X} 2.2$ & 0.827 & 0.5 & Valid \\
\hline $\mathrm{X} 2.3 .2$ & 0.946 & 0.5 & Valid & $\mathrm{X} 2.3$ & 0.624 & 0.5 & Valid \\
\hline Y.1.1 & 0.897 & 0.5 & Valid & $\mathrm{Z1}$ & 0.916 & 0.5 & Valid \\
\hline Y.1.2 & 0.869 & 0.5 & Valid & $\mathrm{Z} 2$ & 0.893 & 0.5 & Valid \\
\hline Y.2.1 & 0.871 & 0.5 & Valid & $\mathrm{Z3}$ & 0.898 & 0.5 & Valid \\
\hline Y.2.2 & 0.895 & 0.5 & Valid & Z4 & 0.847 & 0.5 & Valid \\
\hline Y.3.1 & 0.881 & 0.5 & Valid & Y1 & 0.840 & 0.5 & Valid \\
\hline Y.3.2 & 0.885 & 0.5 & Valid & Y2 & 0.798 & 0.5 & Valid \\
\hline Y.4.1 & 0.892 & 0.5 & Valid & Y3 & 0.837 & 0.5 & Valid \\
\hline Y.4.2 & 0.878 & 0.5 & Valid & Y4 & 0.832 & 0.5 & Valid \\
\hline Y.5.1 & 0.935 & 0.5 & Valid & Y5 & 0.791 & 0.5 & Valid \\
\hline Y.5.2 & 0.938 & 0.5 & Valid & Y6 & 0.807 & 0.5 & Valid \\
\hline
\end{tabular}

Source: Data Processing (2021) 
Based on the loading factor value in table 6 , it is found that of the all question indicators are valid because they have a loading factor value more than 0.5 . So that all the statements listed in the questionnaire above are eligible to reflect the variables in the study. To assess discriminant validity using the square root of AVE value for each construct. If the AVE value of each construct is greater than 0.50 , it is said that the construct has a good validity discriminant value. The AVE value for each construct can be seen in table 7 below:

\begin{tabular}{cccc}
\hline Construct & AVE & Critical & Result \\
\hline X1 & 0.711 & 0.5 & Valid \\
X2 & 0.532 & 0.5 & Valid \\
Y & 0.539 & 0.5 & Valid \\
Z & 0.665 & 0.5 & Valid \\
\hline \multicolumn{4}{c}{ Source: Data Processing (2021) }
\end{tabular}

Based on the AVE value of each construct in the table above, it shows that the value is greater than 0.50 , which means that each of these constructs has good discriminant validity. Based on table 2 and table 3 about the validity of the four research variables and their construct, it can be seen that all statement items from the four variables are valid. So that all the statements listed in the questionnaire above are eligible to reflect the variables in the study.

\section{Reliability Test}

After measuring the convergent validity and measuring the discriminant validity, finally the internal eliability test was carried out which was measured by two criteria, namely composite reliability and Cronbach alpha from the indicator block measuring the variables. The construct is declared reliable if the composite reliability and Cronbach alpha value is above 0.70 (Ghozali, 2013).

\begin{tabular}{ccc}
\hline Laten & Cronbach's Alpha & Composite Reliability \\
\hline X1 & 0.942 & 0.952 \\
X2 & 0.872 & 0.900 \\
Y & 0.922 & 0.933 \\
Z & 0.927 & 0.941 \\
\hline \multicolumn{3}{c}{ Source: Data Processing (2021) }
\end{tabular}

Based on table 4 regarding the reliability test of the three research variables obtained from a sample of 193 respondents, the results of the reliability test for each variable have good reliability, indicated by the reliability coefficient exceeding the critical value (0.7). Therefore, all statements in the questionnaire can be analyzed further.

\section{Inner Model Evaluation}

\section{R Square}

Based on the test results with SmartPLS 3.0, the results obtained R Square as table 9 below:

\begin{tabular}{ccc}
\hline Endogen & R Square & Relationship \\
\hline Work Life Balance $(\mathrm{Z})$ & 0.540 & Moderate \\
Employee Performance $(\mathrm{Y})$ & 0.688 & Strong \\
\hline
\end{tabular}

Source: Data Processing (2021)

From the results of table 9 the R-Square for the variable Work Life Balance (Z) as big as 0.540 which means that Flexible Work Arrangement (X1) and Work Environment (X2) contribute an influence of 0.540 or $54.0 \%$ to Work Life Balanze $(Z)$ in moderate category. While the remaining $46.0 \%$ is the influence of other factors that are not observed. And R-Square for variable Employee Performance (Y) as big as 0.688 which means that Flexible Work Arrangement (X1), Work Environment (X2), and Work Life Balance (Z) contribute an influence of 0.688 or $68.8 \%$ to Employee Performance (Y) in strong category. While the remaining $31.2 \%$ is the influence of other factors that are not observed.
Influence of

Flexible Work

Arrangement and

Work

Environment on

Employee

Performance

Through Work-

Life Balance

Table 7

AVE Value in

each Construct

Table 8

Table of

Reliability Test

Results

Table 9

R Square 
Table 10

F Square

Table 11

Value T-Table

\section{Table 12}

Results of Path

Coefficient Values, $\mathrm{T}$-count, and $\mathrm{P}$ value

\begin{tabular}{lcl}
\hline \multicolumn{1}{c}{ Variable } & \multicolumn{1}{c}{ Effect Size } & Rating \\
\hline \multicolumn{3}{c}{ Work Life Balance $(\mathrm{Z})$} \\
$\begin{array}{l}\text { Flexible Work Arrangement } \\
\left(X_{1}\right)\end{array}$ & 0.747 & Big \\
Work Environment $\left(X_{2}\right)$ & 0.157 & Medium \\
\multicolumn{3}{c}{ Employee Performance $(Y)$} \\
Flexible Work Arrangement & 0.155 & Medium \\
$\left(X_{1}\right)$ & 0.080 & Small \\
Work Environment $\left(X_{2}\right)$ & 0.372 & Big \\
Work Life Balance $(Z)$ &
\end{tabular}

Source: Data Processing (2021)

Based on table 10 it can be seen that it shows the influence of latent variable predictors at the structural level. On variable Flexible Work Arrangement (X1) have an influence with a big category in influencing Work Life Balance (Z), and Work Environment (X2) have an influence with a medium category in influencing Work Life Balance (Z). While Flexible Work Arrangement (X1), Work Environment (X2), and Work Life Balance (Z) each have an influence to Employee Performance (Y) with medium, small, and big category in influence.

\section{Hypothesis Testing}

\begin{tabular}{ccc}
\hline & One tailed & Two tailed \\
\hline t-table & 1.64 & 1.96 \\
\hline \multicolumn{2}{c}{ Source: Ghozali, (2014) }
\end{tabular}

Testing Criteria:

1. If the value of t-statistics $>\mathrm{t}$-table, then $\mathrm{H} 0$ is rejected and $\mathrm{H} 1$ is accepted

2. If the value of t-statistics $<\mathrm{t}$-table, then $\mathrm{H} 0$ is accepted and $\mathrm{H} 1$ is rejected

From the results of calculations using smartPLS, the magnitude of the t-count significance value in the table below states the magnitude of the significance value between the variables tested. The t-count value states the significance value between Flexible Working Arrangement (X1), Work Environment (X2), Work Life Balance (Z) and Employee Performance (Y) variables.

\begin{tabular}{|c|c|c|c|c|}
\hline Hypothesis & Path Coefficient & T-count & P value & Conclusion \\
\hline$X_{1-P}$ & 0.609 & 12.756 & 0.000 & Accept H1 \\
\hline$X_{2}->Z$ & 0.279 & 4.680 & 0.000 & Accept H2 \\
\hline $\mathbf{X}_{1->} \mathbf{Y}$ & 0.301 & 5.307 & 0.000 & Accept H3 \\
\hline $\mathbf{X}_{2}->\mathrm{Y}$ & 0.177 & 2,673 & 0.008 & Accept H4 \\
\hline $\mathbf{Z}->\mathbf{Y}$ & 0.502 & 8,211 & 0.000 & Accept H5 \\
\hline $\mathbf{X}_{1->} \mathbf{Z}->\mathbf{Y}$ & 0.306 & 7.122 & 0.000 & Accept H6 \\
\hline $\mathbf{X}_{2->} \mathbf{Z}->\mathbf{Y}$ & 0.140 & 4.039 & 0.000 & Accept H7 \\
\hline
\end{tabular}

Source: Data Processing (2021)

Based on the results of the quantitative analysis that has been carried out, it is known that all hypothesis in this study are accepted. This shows that employee performance can be driven by aspects of Flexible Work Arrangement, Work Environment and Work Life Balance. For profit-oriented organizations, employee performance is one of the keys to success in improving organizational performance (Zainie et al., 2015). The following is a description of the table12 about hypothesis testing.

Hypothesis 1 was accepeted due to the $\mathrm{t}$ count of $\mathrm{H} 1$ which greater than $\mathrm{t}$ table and the $\mathrm{P}$-value is less than 0.005. It can be concluded that Flexible Work Arrangement has a significant positive effect on Work Life Balance. This means that flevible work arrangement has a positive and significant impact on the aspects of the Work Life Balance of employees. Employees can carry out activities that they previously could not do because they 
previously collided with the time and place of formal work. In addition, if employees perform FWA, the stress experienced by employees will be reduced and will trigger an increase in aspects of Work Life Balance. This state happened because when employees do FWA, they free to choose the time and place of work so that they can save time, energy, and transportation costs to get to the office. Time savings can be used to do other things so employees will be more productive in carrying out other activities (including their personal activities).

Hypothesis 2 was accepeted due to the t count of $\mathrm{H} 2$ which greater than t table and the P-value is less than 0.005. It can be concluded that Work Environtment has a significant positive effect on Work Life Balance. The influence of the work environment on Work Life Balance is very broad, meaning that each individual employee has his own preferences and standards for his Work Life Balance aspects. Similarly, the work environment can be a preference for everyone. During the Covid-19 pandemic, Telkom employees, especially Region 3 West Java, began to implement FWA which allowed employees to work freely from anywhere. Work environment preferences when doing FWA or WFH can be fully determined by employees, so employees will feel more comfortable with their own work environment. The comfort that is obtained at work can improve aspects of Work Life Balance because the employee gets self-satisfaction.

Hypothesis 3 was accepeted due to the $\mathrm{t}$ count of $\mathrm{H} 3$ which greater than $\mathrm{t}$ table and the $\mathrm{P}$-value is less than 0.005. It can be concluded that Flexible Work Arrangement has a significant positive effect on Employee Performance. This can happen because the employee must choose the time and place according to his preferences so that there will be comfort which can have a positive impact on his performance. One of the dimensions of a flexible work arrangement is that flexy time is not suitable for all types of industries. Industries such as manufacturing, construction, and transportation are more difficult to apply the concept of flexy time. Unlike the case with Telkom which is suitable to apply the concept of flexy time because it is in the digital-telco industry which demands high flexibility. During the Covid-19 pandemic in 2020, Telkom managed to increase its revenue from the previous year. This happens because the influence of the Flexy Working Arrangement method carried out by Telkom management is considered appropriate and favored by Telkom employees, as evidenced by the increase in Telkom's operational performance during 2020.

Hypothesis 4 was accepeted due to the $\mathrm{t}$ count of $\mathrm{H} 4$ which greater than $\mathrm{t}$ table and the P-value is less than 0.005. It can be concluded that Work Environment has a significant positive effect on Employee Performance. The work environment in this research is a dynamic work environment where when this research was conducted, the Covid-19 pandemic was occurring so that the employee's work environment was home, office, or other places. A good work environment will also have a good impact on employee performance, so having a conducive work environment is a must for an employee. So, it can be concluded that the dynamic work environment during this pandemic did not reduce the performance of Telkom Regional-3 employees.

Hypothesis 5 was accepeted due to the $\mathrm{t}$ count of $\mathrm{H} 5$ which greater than $\mathrm{t}$ table and the P-value is less than 0.005 . It can be concluded that Work Life Balance has a significant positive effect on Employee Performance. Employee performance resulting from employees who get a balance between work life and personal life usually has a much better level of performance. So, if the employee's Work Life Balance is not maintained properly by the company, it will have a negative impact on the company and the employees themselves. In this Covid-19 pandemic, Telkom employees have the choice to be able to determine their own workplace and time. This can be an advantage because employees can carry out several roles at a time, for example when working at home employees can carry out their roles as family members. In addition, if employees choose to do their work from tourist attractions, personal life aspects will be more fulfilled because they can feel the experience of working in tourist attractions. The state of the Covid-19 pandemic where all community movements are restricted by the government increases the aspect of the Work Life Balance of employees which has an impact on employee performance.

Hypothesis 6 was accepeted due to the t count of H6 which greater than t table and the P-value is less than 0.005. It can be concluded that Flexible Work Arrangement has a significant positive effect on Employee Performance through Work Life Balance. Flexible Work Arrangement being an exogenous variable has a significant effect on employee performance directly. However, this study also looks at the relationship between the two exogenous variables on employee performance indirectly through the intervening/mediation variable of Work Life Balance. These exogenous variables have a significant effect on Employee Performance through Work Life

\section{DISCUSSION}

The first hypothesis of this research is how the effect of Flexible Work Arrangement on Work Life Balance at Telkom Regional 3 during the Covid-19 pandemic. Based on the hypothesis test that has been done, it can be concluded that Flexible Work Arrangement has a significant positive effect on Work Life Balance. This is in accordance with research conducted by Stefanie et al., (2020) which states that the flexibility of the way of working provided by the company has a positive and significant effect on aspects of the Work Life Balance of employees. In addition, according to Stefanie et al., (2020) during this pandemic, the employee's Work Life Balance aspect is more fulfilled because of the contribution of the company's Flexible Work Arrangement practice. Employees can carry out activities that previously could not be done because previously constrained by time and formal 
workplace. Another study on Flexible Work Arrangement has a significant positive effect on aspects of Work Life Balance, which was also conducted by (Maharani et al., 2020). Maharani et al., (2020) said that when employees perform FWA, the stress experienced by employees will be reduced and will trigger an increase in aspects of Work Life Balance. This can happen because when employees do FWA, they are free to choose the time and place of work (according to the boss's permission) so they can save time, energy and transportation costs to get to the office. The time saved can be used to do other things to make employees more productive.

Mattis, (1990) through Pandiangan, (2018) states that flexible working hours can increase job satisfaction, where currently wages are not the benchmark that employees are looking for but other benefits such as time and hours of work, facilities provided by the company, and the promised career journey. All of this refers to the concept of Work Life Balance which is a combination of aspects of work life and aspects of personal life. In addition, Enre et al., (2020) in their research found that when doing WFH employees were not worried about being exposed to the Covid-19 virus, so they could move more comfortably.

The second hypothesis of this research is how the influence of the work environment on the work life balance. Based on the hypothesis test that has been done, it can be concluded that the Work Environment has a significant positive effect on Work Life Balance. This is in accordance with research conducted by Aifha \& Suwarsi, (2018) at PT. Pos Indonesia which states that the work environment has a significant effect on aspects of Work Life Balance. Aifha \& Suwarsi, (2018) in their research also said that companies must retain their employees as long as possible in order to continue to maintain their existence in business competition, one of the most effective ways to make employees feel at home is to fulfil the Work Life Balance Aspects that employees need.

Another study with similar results conducted by Anila \& Krishnaveni, (2016) stated that the work environment has a significant positive effect on aspects of Work Life Balance. In addition, according to Anila \& Krishnaveni, (2016) the influence of the work environment on Work Life Balance is very broad, meaning that each individual employee has their own preferences and standards for aspects of their Work Life Balance. Similarly, the work environment can be a preference for everyone. During the Covid-19 pandemic, Telkom employees, especially Regional 3 West Java, began to implement FWA which allows employees to work freely from anywhere. The preference of the work environment when doing FWA or WFH is entirely determined by the employee, so that employees will feel more comfortable with their own work environment. The comfort obtained at work can improve aspects of Work Life Balance because employees get self-satisfaction (Nurwahyuni, 2019).

The third hypothesis of this study is how the effect of Flexible Work Arrangements on Employee Performance. Based on the hypothesis test that has been done, it can be concluded that Flexible Work Arrangement has a significant positive effect on employee performance. This is in line with research conducted by Kipkoech, (2018) that Flexible Work Arrangement has a significant positive effect on employee performance. Working with flexible working hours can improve employee performance (Kipkoech, 2018). This can happen because employees must choose a time and place that suits their preferences so that a sense of comfort will arise which can have a positive impact on their performance (Tumbel et al., 2017).

In line with this study, there is research from Abid \& Barech, (2017) which reveals that the Flexible Work Arrangement variable has a significant positive effect on the Employee Performance variable. This study highlights that one dimension of flexible work arrangements, namely flexible time, is not suitable for all types of industries. Industries such as manufacturing, construction, and transportation are more difficult to apply the concept of flexible time. Unlike the case with Telkom which is suitable to apply the concept of flexy time because it is in the digital-telco industry which demands high flexibility.

During the Covid-19 pandemic in 2020, Telkom managed to increase revenue from the previous year. This happens because the way the work carried out by the management of Telkom Flexy is considered their own right as well as being liked by Telkom employees, as evidenced by the improvement in Telkom's operational performance during 2020. In accordance with Armstrong's opinion through the book Sopiah \& Sangadji, (2018) which states that one of the factors that affect employee performance are system factors related to work methods, in the context of this study the Flexible Work Arrangement variable.

The next hypothesis that is accepted is the influence of the Work Environment on Employee Performance. The answer to the fourth hypothesis in this study has similarities with research from Hastutiningsih, (2019), namely the work environment has a significant positive effect on employee performance. Hastutiningsih, (2019) also states that employee performance can be influenced by internal and external factors, in this study the work environment is an external factor that can affect employee performance.

The work environment in this study is a dynamic work environment where at the time this research was conducted there was a Covid-19 pandemic so that the employee's work environment was home, office, or another place. This is reinforced by the opinion of Indarti et al., (2014) that the work environment is a factor outside of humans, both physical and non-physical in an organization that can affect performance. In line with research from Hustia, (2020) which found that the work environment had a significant positive effect on employee performance. As stated by Hustia, (2020) in his research that a good work environment will also have a good impact on employee performance, so having a conducive work environment is a must for an employee. Therefore, it can be concluded that the dynamic work environment during this pandemic does not reduce the performance of 
The fifth hypothesis that is accepted in this study is that Work Life Balance has an effect on employee performance. This is in accordance with research conducted by Nurwahyuni, (2019) at Telkom Regional V East Java. Nurwahyuni, (2019) in her research states that the performance resulting from employees who get a balance between work life and personal life usually has a much better level of performance. Therefore, if the employee's Work Life Balance is not maintained properly by the company, it will have a negative impact on the company and the employees themselves.

During this Covid-19 pandemic, Telkom employees have the choice to be able to determine their own workplace and time. This can be an advantage because employees can carry out several roles at the same time, for example when working at home employees can carry out their roles as family members. In addition, if employees choose to do their work from a tourist place, aspects of their personal life will be more fulfilled because they can feel the experience of working in a tourist place. Wolor et al., (2020) and Ratnawati et al., (2020) in their research on the relationship of Work Life Balance to employee performance during the pandemic simultaneously also argue that the Work Life Balance variable has a significant positive effect on the Employee Performance variable. The state of the Covid-19 pandemic where all community movements are restricted by the government increases aspects of the Work Life Balance of employees which has an impact on employee performance.

Flexible Work Arrangements and work environment which are exogenous variables have a significant direct effect on employee performance. However, this study also looks at the relationship between the two exogenous variables on employee performance indirectly through the intervening/mediation variable of Work Life Balance. Both exogenous variables have a significant effect on Employee Performance through Work Life Balance. Meanwhile, for employees of Telkom Regional 3 West Java, the exogenous variable that has the greatest direct or indirect influence on employee performance is the Flexible Work Arrangement variable. While the direct or indirect relationship of the Work Environment variable to Employee Performance is weaker than the influence caused by the Flexible Work Arrangement variable.

\section{CONCLUSION}

After the author discussed in the previous chapter the description of the effect of flexible work arrangements and work environment on employee performance through work life balance, the authors in this chapter will try to draw conclusions and provide suggestions based on the description. which was stated in the previous chapter. Flexible work arrangements, work environment, and work life balance of Treg-3 employees during the Covid-19 pandemic are in the high category, the performance of Treg-3 employees during the Covid-19 pandemic is in the very high category. This shows that the working atmosphere at Treg- 3 during the Covid-19 pandemic is quite conducive. And all hypotheses can be accepted based on statistical calculations that have been done.

For further research, it is possible to conduct research not only on the dependent variable of employee performance, but also the level of employee satisfaction and employee engagement. In addition, further research can also use aspects of leadership with an online context in determining the level of employee performance. In addition, studies in the field of human resource management during the Covid-19 pandemic are still very few, this research can be used as a reference. In addition, if in the future there is another pandemic with a similar work situation, this research can be used as a reference in making decisions.

In this study it is known that the flexible work arrangement method can increase the level of employee performance. Therefore, Telkom must continue to apply this way of working even though the pandemic has ended. Based on the research conducted, the flexible work arrangement method provides work effectiveness and efficiency for Treg-3 employees so that it can directly or indirectly benefit Telkom.

In this study also found the influence of work life balance aspects on employee performance is quite large. So that if Telkom can improve the work life balance aspect of its employees, the company's performance will also increase. During this pandemic, most of the employee's working time is spent from home and the working hours are too flexible resulting in frequent video conferences or other tasks that must be done at night. If this condition does not change within a certain period, this can lead to a decrease in the aspect of work-life balance due to reduced quality time with family and normal rest time. One way that Telkom can do to keep the work life balance aspect of its employee high is to make a policy regarding working time limits.

Based on the research conducted, the influence of the work environment on employee performance is the lowest, either directly or indirectly. So that Telkom and Treg-3 must be able to ensure a conducive work environment for employees when carrying out flexible work arrangements. In addition, this control function is still needed so that employees do not lose control and stay on track to achieve the goals set by the company. This control function can be obtained from the employee's direct supervisor in the form of supervision from the supervisor, or it can be in the form of other tools such as mobile apps or other IT tools. The company's efforts to adapt quickly in this pandemic era require the formulation of the right strategy. Based on the current situation, 
flexible work arrangements can be one solution that can be calculated and applied by companies in similar industries to keep operating during the Covid-19 pandemic.

\section{Reference}

Abid, S., \& Barech, D. K. (2017). The Impact of Flexible Working Hours On The Employees Performance. International Journal of Economics, Commerce and Management, 5(7), 450-466. http://ijecm.co.uk/

Aifha, S. N., \& Suwarsi, S. (2018). Pengaruh Lingkungan Kerja dan Stres Kerja terhadap Work Life Balance di PT . Pos Indonesia ( Persero ) Bandung. Prosiding Manajemen, 4, 349-355.

Enre, U. M., Tri, C., Rokhani, S., \& Ag, S. (2020). Pengaruh Work From Home (WFH) Terhadap Kinerja Guru SD Negeri Dengkek 01 Pati Selama Masa Pandemi Covid-19. 2.

Garg, P., \& Yajurvedi, N. (2016). Impact of Work-Life Balance Practices on Employees Retention and Organizational Performance - A Study on IT Industry. August, 105-108.

Ghozali, I. (2014). Structural Equation Modeling, Metode Alternatif dengan Partial Least Square (PLS) (4th ed.).

Handayani, A., \& Munawar, M. (2015). Work-Family Balanced and Quality of Parenting in Optimizing Children Development. Ndonesian Journal of Early Childhood Education Studies. https://doi.org/10.15294/ijeces.v4i1.9447

Hartono, A., \& Rahadi, D. R. (2021). Work From Home Terhadap Kinerja Karyawan Pada Masa Pandemi Covid 19. Jurnal Manajemen Bisnis, 18(1), 16-21. https://doi.org/10.38043/jmb.v18i1.2728

Hastutiningsih, A. T. (2019). Pengaruh beban kerja dan lingkungan kerja terhadap kinerja karyawan dimediasi stres kerja. Prosiding National Conference on Applied Business, 1-8.

Hustia, A. (2020). Pengaruh Motivasi Kerja, Lingkungan Kerja Dan Disiplin Kerja Terhadap Kinerja Karyawan Pada Perusahaan WFO Masa Pandemi. Jurnal Ilmu Manajemen, 10(1), 81. https://doi.org/10.32502/jimn.v10i1.2929

Indarti, S., Hendriani, S., \& Mahda, M. (2014). PENGARUH FAKTOR KEPRIBADIAN PEGAWAI DAN LINGKUNGAN KERJA TERHADAP KINERJA PEGAWAI PADA KANTOR REGIONAL XII BKN PEKANBARU. JURNAL EKONOMI Volume 22, Nomor 1 Maret 2014.

K, A., \& Krishnaveni, V. (2016). INFLUENCE OF FAMILY ENVIRONMENT AND WORK ENVIRONMENT ON WORK LIFE BALANCE AMONG WOMEN EMPLOYEES. 6(3), 15-17.

Kipkoech, K. V. (2018). Flexible Working Arrangements on Employee Performance in Kericho County Referral Hospital. Ir-Library.Ku.Ac.Ke, 85. https://ir-library.ku.ac.ke/bitstream/handle/123456789/18583/Flexible working arrangements on employee performance in....pdf? sequence $=1 \&$ is Allowed=y

Maharani, A., Gofika, S. I., Mahlani, S. A., \& Berlian, C. W. (2020). Flexible Working Arrangement, Stress, Work Life Balance, and Motivation: Evidence from Postgraduate student as worker.pdf. Jurnal Organisasi Dan Manajemen.

Mathis, R. L., \& Jackson, J. H. (2014). Human Resource Management.

Nurwahyuni, S. (2019). Pengaruh Beban Kerja Terhadap Kinerja Karyawan Melalui Work Life Balance (Studi Kasus PT. Telkom Indonesia Regional V). Jurnal Ilmu Manajemen (JIM), 7(1), 1-9.

Pandiangan, H. (2018). Flexible Working Arrangement dan Pengaruhnya Terhadap Work Life Balance pada Driver Layanan Jasa Transportasi Online di Kota Yogyakarta.

Ratnawati, H., Putranti, D., \& Suparmi, S. (2020). Work Life Balance (WLB ) Complexity and Performance of Employees during Covid-19 Pandemic. Journal of Business Management and Accounting, 4(1), 56-68.

SHRM. (2015). SHRM Research: Flexible Work Arrangements.

Sopiah, \& Sangadji, E. (2018). Manajemen Sumber Daya Manusia Strategik. 
Stefanie, K., Suryanti, E., \& Maharani, A. (2020). Flexible Work Arrangement, Work Life Balance, Kepuasan Kerja, dan Loyalitas Karyawan pada Situasi Covid-19. JIMEA, 3.

Tumbel, T. M., Pangemanan, F. L., \& Pio, R. J. (2017). Pengaruh Work Life-Balance dan Burnout Terhadap Kepuasan Kerja. 1-8.

Ulrich, D., Becker, B. E., \& Huselid, M. A. (2001). The HR SCORECARD - Linking People, Strategy, and Performance. President and Fellows of Harvard College.

Wolor, C. W., Solikah, S., Fidyallah, N. F., \& Lestari, D. P. (2020). Effectiveness of E-Training, E-Leadership, and Work Life Balance on Employee Performance during COVID-19. Journal of Asian Finance, Economics and Business, 7(10), 443-450. https://doi.org/10.13106/jafeb.2020.vol7.no10.443
Influensce of Flexible Work

Arrangement and Work

Environment on Employee

Performance

Through WorkLife Balance 